\title{
Can three-dimensional anorectal ultrasonography be included as a diagnostic tool for the assessment of anal fistula before and after surgical treatment?
}

\author{
Sthela Maria MURAD-REGADAS ${ }^{1,2,3}$, Francisco Sergio P REGADAS FILHO ${ }^{3}$, Erico de Carvalho HOLANDA', \\ Lara Burlamaqui VERAS ${ }^{3}$, Adjra da Silva VILARINHO ${ }^{3}$ and Manoel S LOPES ${ }^{1}$
}

Received 28/1/2018

Accepted 3/7/2018

\begin{abstract}
Background - There is no a clear knowledge concerning the division of any part of the anal sphincter complex and the effect of this procedure on the function of the anal canal during the treatment of perianal fistula. Objective - To evaluate the usefulness of 3D anorectal ultrasound in the assessment of anal fistula, quantifying the length of the sphincter muscle to be transected, selecting patients for different approaches and identifying healing, failure or recurrence after the surgical treatment. Methods - A prospective study included patients with primarily cryptogenic transsphincteric anal fistula assessed by fecal Incontinence score, tri-dimensional anorectal ultrasound and anal manometry before and after surgery. Based on 3 D-AUS, patients with $\geq 50 \%$ external sphincter or external sphincter+puborectalis muscle involvement in males and $\geq 40 \%$ external sphincter or external sphincter+puborectalis muscle in females were referred for the ligation of the intersphincteric tract (LIFT) or seton placement and subsequent fistulotomy; and with $<50 \%$ involvement in males and $<40 \%$ in females were referred to one-stage fistulotomy. After surgery, the fibrosis (muscles divided) and residual muscles were measured and compared with the pre-operative. Results - A total of 73 patients was included. The indication for the LIFT was significantly higher in females (47\%), one-stage fistulotomy was significantly higher in the males (46\%) and similar in seton placement. The minor postoperative incontinence was identified in 31\% of patients underwent sphincter divided and were similar in both genders. The 3D-AUS identified seven failed cases. Conclusion - The 3D ultrasound was shown to be an effective method in the preoperative assessment of anal fistulas by quantifying the length of muscle to be divided, as the results were similar at the post-operative, providing a safe treatment approach according to the gender and percentage of muscle involvement. Additionally, 3D ultrasound successfully identified the healing tissue and the type of failure or recurrence. HEADINGS - Anorectal malformations. Rectal fistula. Fecal incontinence. Ultrasonics.
\end{abstract}

\section{INTRODUCTION}

The management of anal fistulas depends on fistula anatomy and identification of all the components, such as, primary and secondary tract(s) and internal opening(s), as well as the extent of operative sphincter division and association with healing rates and functional compromise ${ }^{(1)}$.

Bi or tri-dimensional ultrasound and magnetic resonance image (MRI) have proven useful in the assessment of fistula-in-ano, with concordance with operative findings in $73 \%$ to $100 \%$ of cases ${ }^{(2-5)}$. Studies have reported some degree of fecal incontinence in up to $73 \%$ of patients who underwent fistulotomy, according to the risk factors of the patient, including preoperative incontinence, recurrent disease, female gender, complex fistulas, and previous fistula surgery ${ }^{(6-9)}$. There is no a clear knowledge concerning the division of any part of the anal sphincter complex and the effect of this procedure on the function of the anal canal during the treatment of perianal fistula, nor concerning the follow-up with images after damage to the anal sphincter. Therefore, this study aimed to evaluate the usefulness of three-dimensional anorectal ultrasound (3D-AUS) in the assessment of anal fistula, quantifying the length of the sphincter muscle to be transected, selecting patients for different approaches and identifying healing, failure or recurrence after the surgical treatment.

\section{METHODS}

Between March 2009 and May 2016, consecutive patients with primarily cryptogenic transsphincteric anal fistula were assessed through the Cleveland Clinic Fecal Incontinence score (CCFIS) ${ }^{(10)}$, 3D-AUS and anal manometry before surgery and within 4 months after wound healing was complete. Subsequently, patients underwent surgery at Hospital das Clínicas (Federal University of Ceará) or at Hospital São Carlos, both of which are in Fortaleza, Brazil. After surgery, the percentage of fibrosis (muscles divided) and residual muscles were measured using 3D-AUS and compared with the pre-operative findings. Anal pressures were measured before and

Declared conflict of interest of all authors: none

Disclosure of funding: no funding received

1 Universidade Federal do Ceará, Faculdade de Medicina, Departamento de Cirurgia, Fortaleza, CE, Brasil. ${ }^{2}$ Universidade Federal do Ceará, Hospital das Clínicas, Unidade do Assoalho

Pélvico e Fisiologia Anorretal, Fortaleza, CE, Brasil. ${ }^{3}$ Hospital São Carlos, Unidade do Assoalho Pélvico e Fisiologia Anorretal, Departamento de Cirurgia Colorretal, Fortaleza, CE, Brasil.

Corresponding author: Sthela Murad Regadas. Orcid: 0000-0002-9905-6981. E-mail: smregadas@hospitalsaocarlos.com.br. 
after surgery. Patients with inflammatory bowel disease, human immunodeficiency virus (HIV), anal sphincter injury, fecal incontinence symptoms and a history of colorectal and proctological surgery or vaginal delivery were excluded. The clinical protocol was approved by the Research Ethics Committee of the Walter Cantídio University Hospital, and all patients gave written informed consent.

\section{Assessments and follow-up \\ - Three-dimensional anorectal ultrasonography (3D-AUS)}

A 3D ultrasound endoprobe (model 2052; $16 \mathrm{MHz}$; focal distance 3.0-3.5 cm, type Pro-Focus, BK Medical ${ }^{\circledR}$ ) was used. Images up to $6.0 \mathrm{~cm}$ in length were automatically captured along the proximal-distal axis, with duration of up to 50 seconds, by moving two crystals on the extremity of the transducer without moving the probe. The examination involved a series of transaxial microsections up to $0.20 \mathrm{~mm}$ thick producing a high-resolution digitalized volumetric image. Volume was displayed as a 3D cube image and recorded and analyzed in multiple planes. Patients were examined in the left lateral position after rectal enema (completed two hours
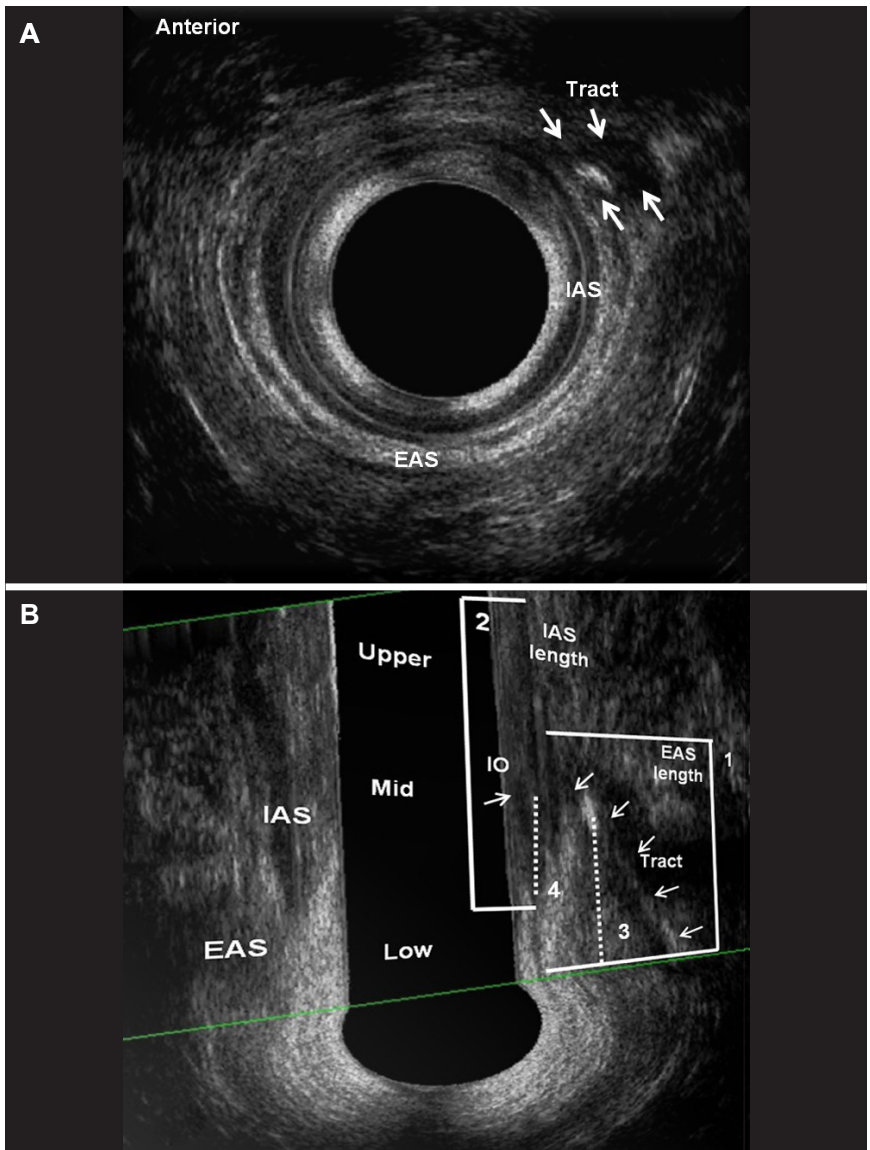

FIGURE 1. Before surgery - hydrogen peroxide-enhanced 3-DAUS image of female patient with anterior transsphincteric fistula in the 13 o'clock position. The length of the EAS (line 1), the IAS (2), the length of the EAS (3-dotted line) and the IAS (4-dotted line) compromised by the fistulous tract are indicated. The tract compromised $>50 \%$ of anterior EAS. (a) Axial plane - mia anal canal. (b) Coronal and oblique plane. EAS: external anal sphincter; IAS: internal anal sphincter; IO: internal opening. prior to scanning). After the digital rectal examination, the endoprobe was introduced as far as the upper anal canal. Two scans were performed. The second scan was performed after injection of 0.3-1.0 mL 10.0\% hydrogen peroxide $\left(\mathrm{H}_{2} \mathrm{O}_{2}\right.$ through the external fistulous opening, using an angiocatheter for infants. The length of the external anal sphincter (EAS), the internal anal sphincter (IAS), the total length of the compromised sphincter (distance from the distal part of each muscle to the point where it was crossed by the fistulous tract) and the percentage of sphincter muscle to be transected (length of the compromised sphincter divided by total muscle length) were measured (FIGURE 1). Based on these findings, patients with $\geq 50 \%$ EAS or EAS plus puborectalis (EASPR) muscle involvement in males and $\geq 40 \%$ EAS or EAS-PR in females were referred for the ligation of the intersphincteric tract (LIFT) or seton placement and subsequent fistulotomy in two or three steps to induce fibrosis. Patients with $<50 \%$ EAS involvement in males and $<40 \%$ EAS involvement in females were referred to one-stage fistulotomy. After surgery, the percentage of the fibrosis (muscles divided) and residual muscles were measured using 3DAUS and compared with the pre-operative findings (FIGURES 1 and 2) (FIGURE 3). The anal pressures were measured before and after surgery.
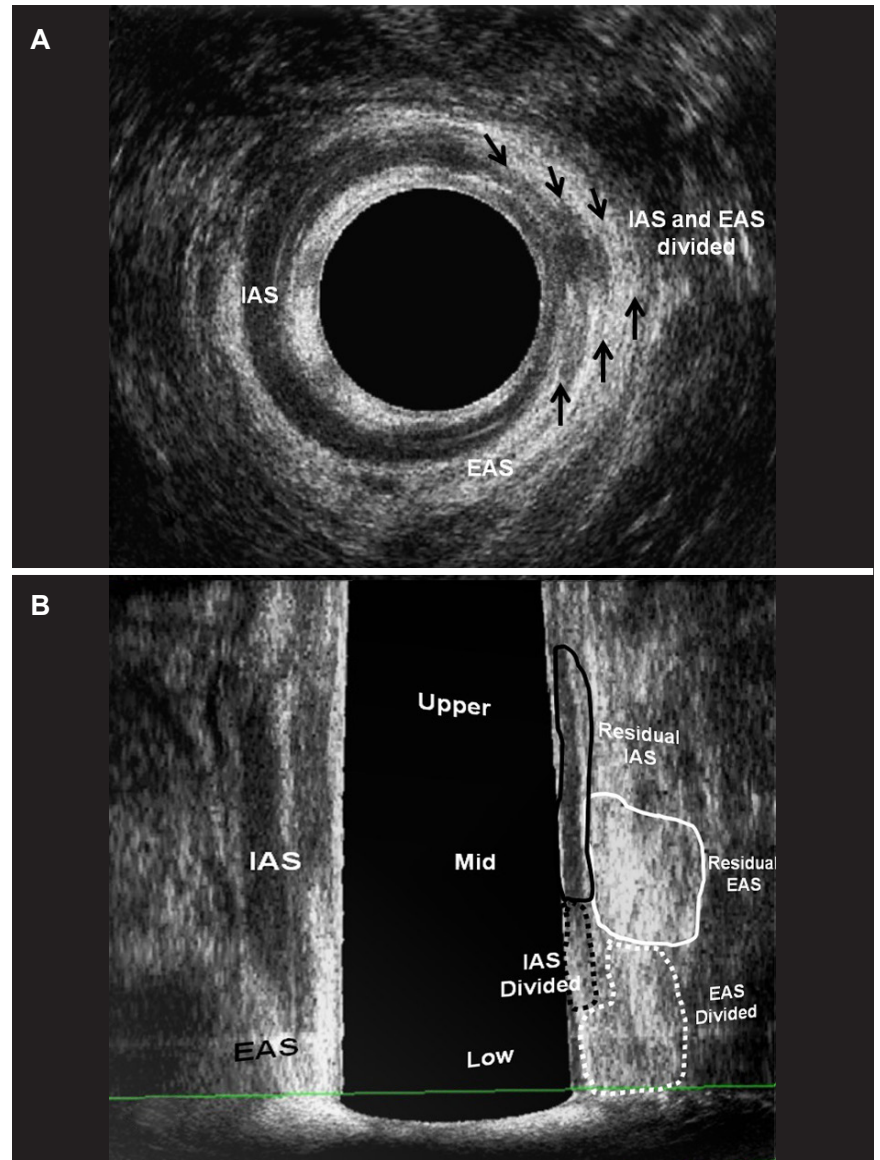

FIGURE 2. After surgery - patient (Fig. 1) underwent seton placement and subsequent fistulotomy in two. (a) Axial plane - the fibrosis that correspond the IAS and EAS divided (arrows). (b) Coronal and oblique plane - the fibrosis - EAS and IAS divided (dotted area) and residual EAS and IAS (area). EAS: external anal sphincter; IAS: internal anal sphincter; IO: internal opening. 

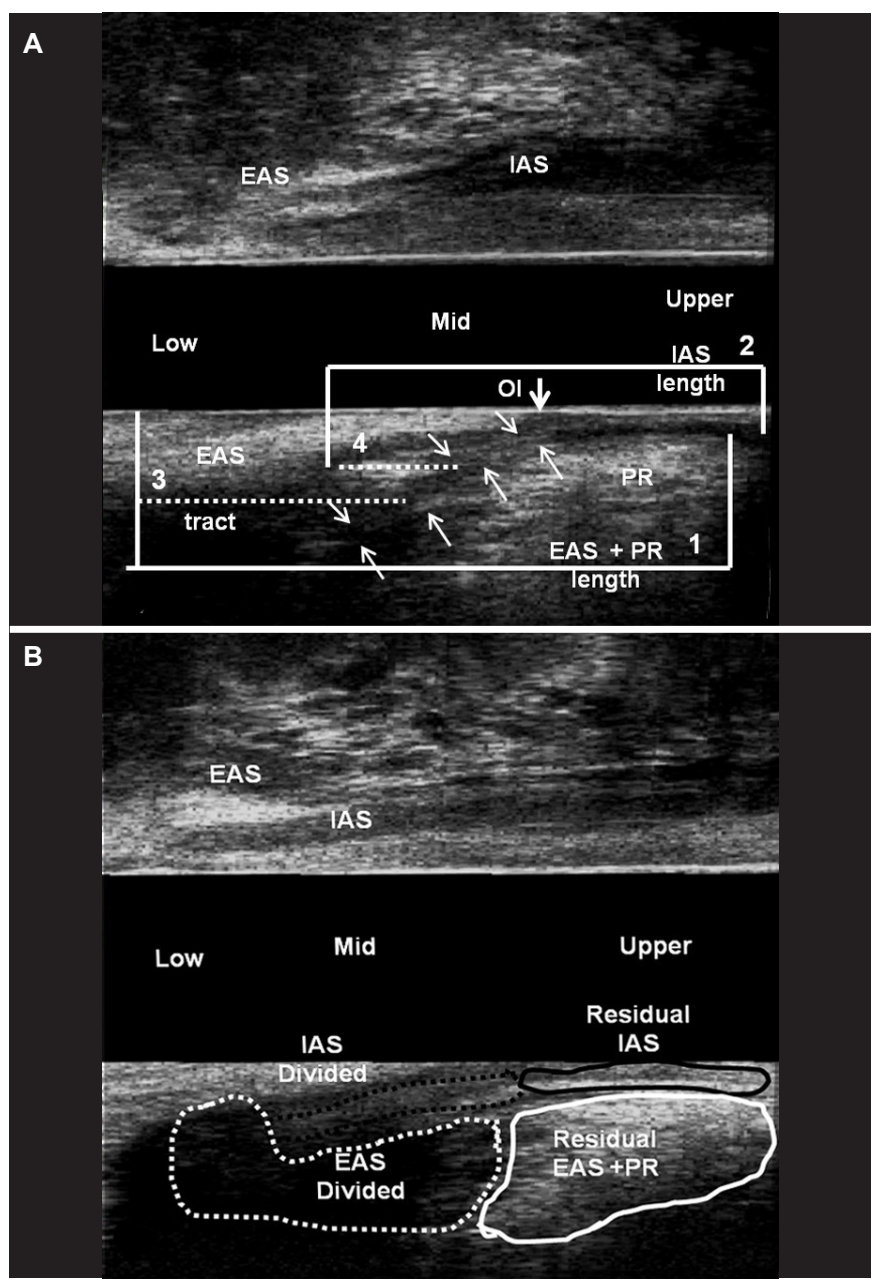

FIGURE 3. (a) Before surgery - hydrogen peroxide-enhanced 3-DAUS image of male patient with posterior transsphincteric fistula in the 6 o'clock position. The length of the EAS+PR (line 1) and the IAS (2), the length of the EAS +PR (3 dotted line) and the IAS ( 4 dotted line) compromised by the fistulous tract are indicated. (b) After surgery sagittal plane - the fibrosis - EAS +PR and IAS divided (dotted area) and residual EAS+PR and IAS (area). EAS: external anal sphincter; EAS+PR: external anal sphincter+puborectal; IAS: internal anal sphincte; PR: puborectal muscle; IO: internal opening.

All patients were examined by a single colorectal surgeon (SMMR) with experience in 3D-AUS and all measurements before surgery and after (within 4 months after wound healing was completed) were blinded.

The operative technique was chosen according to the ultrasound findings and the same expert team of 3 colorectal surgeons specialized in coloproctology (Brazilian Board of Colorectal Surgery) operated all patients.

\section{- Anorectal manometry}

Anorectal manometry was performed in the all patients before surgery and within 4 months after wound healing was complete. A flexible, polyethylene, water-perfused catheter and an 8-channel manometer were used with ProctoMaster software (DynaMed, São Paulo, Brazil) to calculate anal canal pressure at rest and maximum anal squeeze pressure. All evaluations of manometric data were performed by the same examiner.

\section{- Clinical follow-up}

Clinical evaluation of wound healing was performed weekly until the wound healing was complete and incontinence was assessed by means of the CCFIS within 4 months after wound healing was complete.

\section{Statistical analysis}

Males and females were compared with regard to the percentage of EAS, EAS-PR and IAS sphincter muscle to be transected, as well as CCFIS, the percentage of sphincter muscle to be transected and anal pressures before and after surgery within 4 months after wound healing was complete). Differences between groups were assessed by means of Student's $t$-test and one-way ANOVA for continuous data. The level of statistical significance was set at $P<0.05$.

Data were analyzed using SPSS software (version 14.0 for Windows; IBM-SPSS, Chicago, IL).

\section{RESULTS}

\section{Patient characteristics}

A total of 73 patients with median age 39 years (range, 17- 66 years) were eligible ( 39 male and 34 female). All of them did not complain of fecal incontinence and the CCFIS was 0. Of these, in $46(63 \%)$ patients, of both genders, the fistulous tract was positioned in the anterior quadrant. The percentage of the anterior EAS to be transected was significantly higher in the females than the males, while the percentage of anterior internal anal sphincter (IAS) was similar. The percentage of the posterior EAS-PR was similar in both genders, with the percentage of the posterior IAS being significantly higher in the males (TABLE 1).

TABLE 1. 3D-AUS data before surgical treatment for anal fistula.

\begin{tabular}{lccc}
\hline Ultrasound finding & Male & Female & $P$ \\
\hline $\begin{array}{l}\text { Before surgery } \\
\begin{array}{l}\text { Anterior / posterior tract } \\
\text { position }\end{array}\end{array}$ & $39(53 \%)$ & $34(47 \%)$ & \\
$\begin{array}{l}\text { Percentage of anterior EAS } \\
\text { to be transected mean (SD) }\end{array}$ & $44 \%( \pm 19)$ & $59 \%( \pm 16)$ & 0.00 \\
$\begin{array}{l}\text { Percentage of anterior IAS } \\
\text { to be transected mean (SD) }\end{array}$ & $33 \%( \pm 07)$ & $32 \%( \pm 14)$ & 0.86 \\
$\begin{array}{l}\text { Percentage of posterior } \\
\begin{array}{l}\text { EAS-PR to be transected } \\
\text { mean (SD) }\end{array}\end{array}$ & $45 \%( \pm 18)$ & $47 \%( \pm 14)$ & 0.60 \\
$\begin{array}{l}\text { Percentage of posterior IAS } \\
\text { to be transected mean (SD) }\end{array}$ & $38 \%( \pm 12)$ & $22 \%( \pm 08)$ & 0.00 \\
\hline
\end{tabular}

EAS: external anal sphincter; IAS: internal anal sphincter; EAS-PR: external anal sphincter plus puborrectalis muscles.

\section{Operative technique}

The indication for the LIFT procedure was significantly higher in females $(47 \%-16 / 34)$, with seton placement and subsequent fistulotomy in two or three steps $(35 \%-12 / 34)$ and the fistulous tract being positioned in the anterior quadrant. However, in the male patients, the position of the fistulous tract was balanced, comparing anterior with posterior ( $10 \mathrm{vs} 11)$. Of them, $12(31 \%)$ male patients underwent a seton placement and 9 (23\%) LIFT (TABLE 2). 
TABLE2.Treatment Approachaccording togenderand fistulatractposition.

\begin{tabular}{lccc}
\hline Treatment approach (n) & $\begin{array}{c}\text { Male 39 } \\
(53 \%)\end{array}$ & $\begin{array}{c}\text { Female 34 } \\
(47 \%)\end{array}$ & $\boldsymbol{P}$ \\
\hline $\begin{array}{l}\text { Seton placement with } \\
\text { subsequent fistulotomy (n=24) }\end{array}$ & & & \\
$\quad$ Anterior tract position & 04 & 11 & 0.80 \\
$\quad$ Posterior tract position & 08 & 01 & \\
LIFT (n=25) & & & \\
$\quad$ Anterior tract position & 06 & 14 & 0.00 \\
$\quad$ Posterior tract position & 03 & 02 & \\
Fistulotomy (n=24) & & & \\
$\quad$ Anterior tract position & 11 & 00 & 0.01 \\
$\quad$ Posterior tract position & 07 & 06 & \\
\hline
\end{tabular}

LIFT: ligation of the intersphincteric tract.

In total, the LIFT procedure was performed in 25 patients. Of these, 16 were female (14 in the anterior quadrant) and 9 male (6 in the anterior quadrant). The 3D-AUS identified complete healing in $20 / 25(80 \%)$, visualizing fibrosis in the intersphincteric space (IS) and in the extrasphincteric position (EP) previously occupied by the external opening (FIGURES 4 and 5). Of them, in two cases the healing was delayed due to the small persistent cavity in the IS space and the previous EP (FIGURE 6), both of
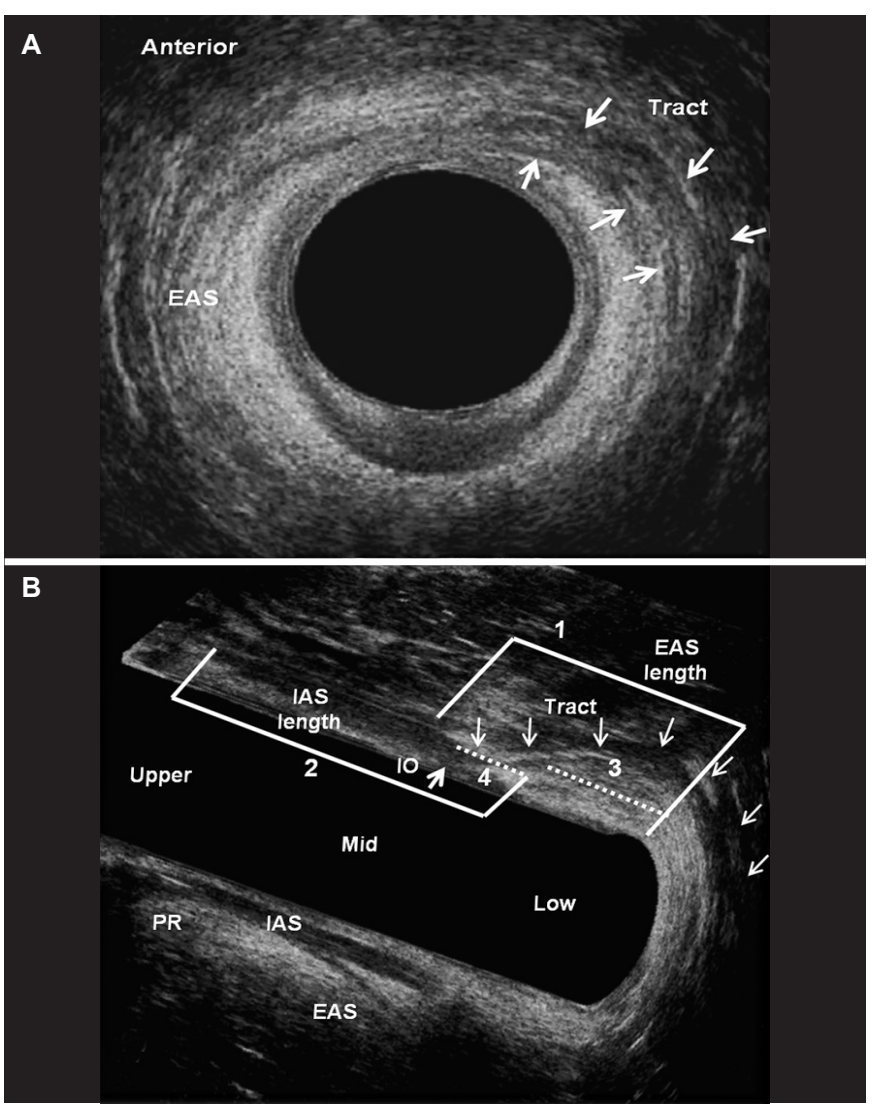

FIGURE 4. Hydrogen peroxide-enhanced 3-DAUS image of female patient with anterior transsphincteric fistula in the 1 o'clock position. The length of the EAS (line 1), the IAS (2), the length of the EAS (3-dotted line) and the IAS (4- dotted line) compromised by the fistulous tract are indicated. The tract compromised $>50 \%$ of anterior EAS. (a) Axial plane mia anal canal. (b) Sagittal and coronal plane. EAS: external anal sphincter; IAS: internal anal sphincter; PR: puborectal muscle; IO: internal opening
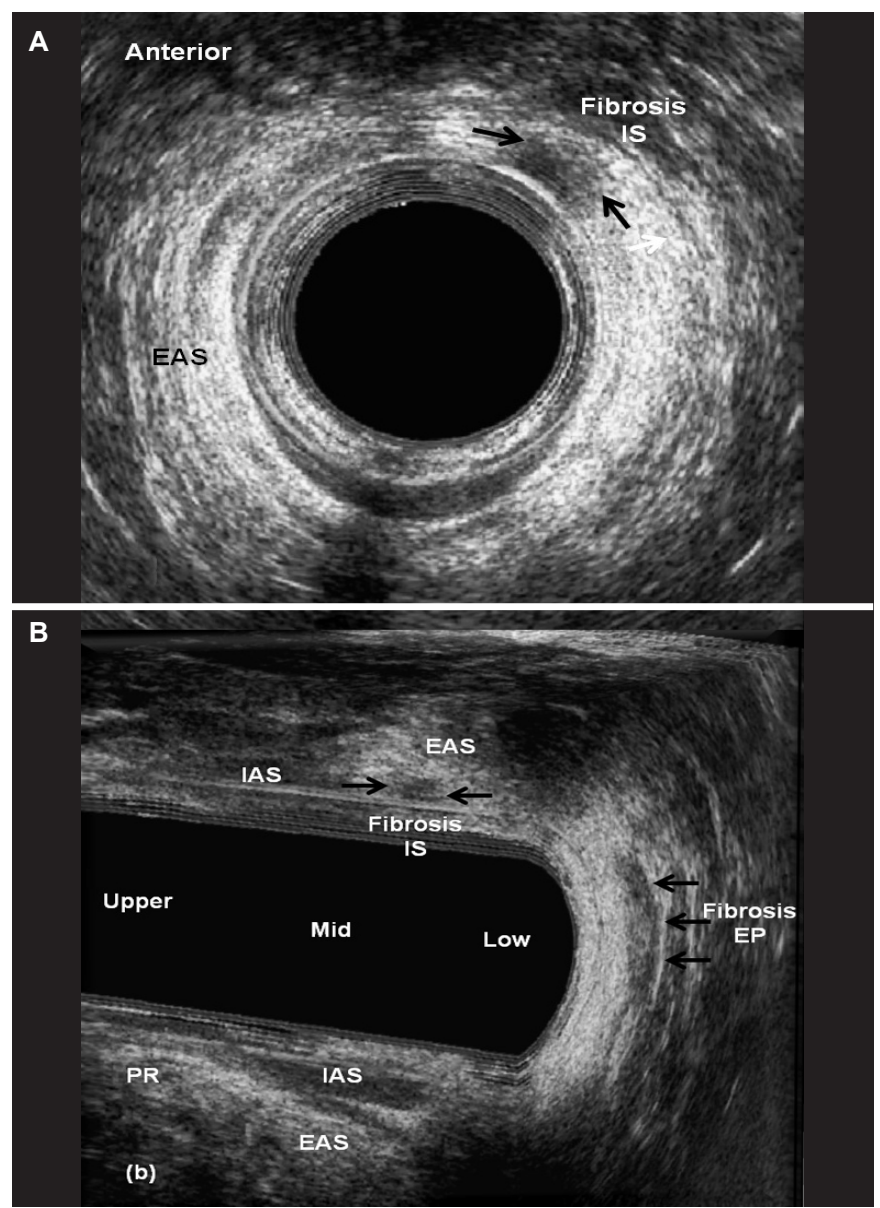

FIGURE 5. After surgery - patient (Fig. 4) underwent a LIFT procedure and identified the complete healing by visualizing fibrosis in the intersphincteric space (IS) and in the extrasphincteric position (EP) previously occupied by the external opening (arrows). (a) Axial plane mid anal canal. (b) Sagittal and coronal plane. EAS: external anal sphincter; IAS: internal anal sphincter; PR: puborectal muscle; IO: internal opening.

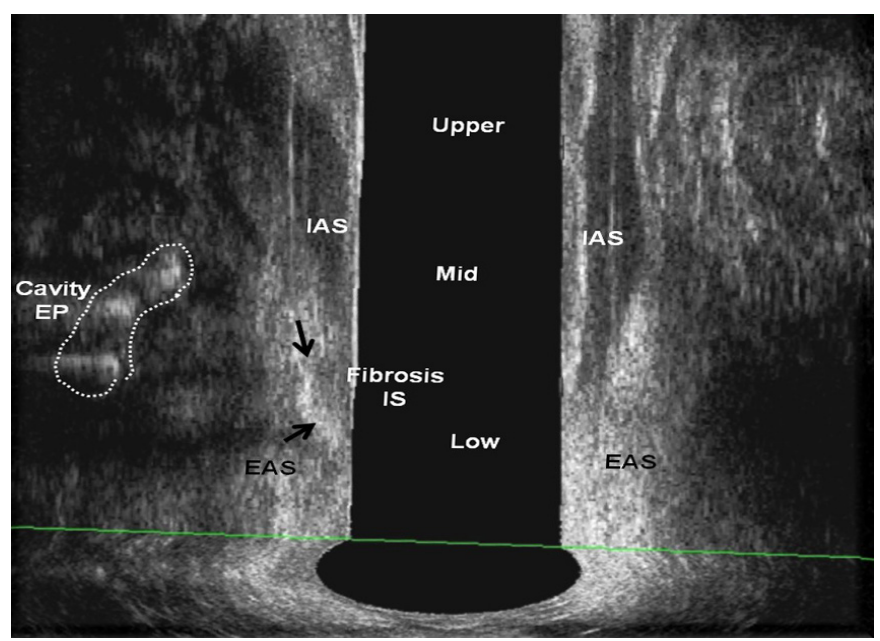

FIGURE 6. After surgery - patient underwent a LIFT procedure and identified small cavity in the extrasphincteric position (EP) (area) and the fibrosis in the intersphincteric space (IS) (arrows). EAS: external anal sphincter; IAS: internal anal sphincter. 
whom were treated conservatively. The 3D-AUS identified five failed cases, one as intersphincteric fistula and four due to recurrences of transphincteric fistula. All of these patients underwent another surgical procedure. Of these, four cases of transphincteric fistula: two underwent LIFT and two seton placement with subsequent fistulotomy and one case of intersphincteric fistula were underwent one-stage fistulotomy.

The indication for one-stage fistulotomy was significantly higher in the male patients $(18 / 39-46 \%)$. Of these, in 11 patients the fistulous tract was positioned in the anterior quadrant. In all the female cases (six) the fistulous tract was positioned in the posterior quadrant (TABLE 2).

\section{Functional outcomes and follow-up}

The median postoperative follow-up was 14 months (range, 6-48 months). The patients were re-assessed 3 to 4 months after complete wound healing by means of the CCFIS, the 3D-AUS examination and anorectal manometry. Overall, minor postoperative fecal incontinence symptoms were identified in 23/73 (31\%) patients and were similar in both genders. Of them, 15 patients underwent seton placement and 8 underwent one-stage fistulotomy (TABLE 3). The median CCFIS was similar comparing the males ( median $=0 /$ range, $0-8$ ) and females (median $=2 /$ range, $0-6$ ). The $3 \mathrm{D}-\mathrm{AUS}$ findings were concordant with the surgical findings in all cases (TABLE 3). The success rate of healing was $96 \%$, identified by $3 \mathrm{D}$-AUS after 4 months in patients that underwent seton placement and one-stage fistulotomy. The percentage of the anterior EAS, anterior IAS, posterior EAS-PR and posterior IAS were similar comparing the percentage of muscles to be transected before surgery with the percentage of fibrosis after sphincter division in both genders, measured by 3D-AUS in patients that underwent of seton placement and one-stage fistulotomy (TABLE 4). There was a significant reduction in resting and squeeze anal pressures after surgery (TABLE 5). The 3D-AUS identified two failed cases, both

TABLE 3. Fecal incontinence symptoms in patients underwent sphincter divided surgical technique.

\begin{tabular}{lccc}
\hline Functional results & $\begin{array}{c}\text { Male } \\
39(53 \%)\end{array}$ & $\begin{array}{c}\text { Female } \\
\mathbf{3 4}(47 \%)\end{array}$ & $\boldsymbol{P}$ \\
\hline Fecal incontinence & $11(28)$ & $12(35)$ & 0.61 \\
FIS median (range) & $0(0-8)$ & $2(0-6)$ & 0.45 \\
Fecal incontinence - & 07 & 08 & 0.57 \\
Seton placement (n=24) & 03 & 07 & \\
$\quad$ Anterior tract position & 04 & 01 & \\
Posterior tract position & 04 & 04 & 1.00 \\
Fecal Incontinence - & 04 & 00 & \\
Fistulotomy (n=24) & 00 & 04 & \\
Anterior tract position & & & \\
Posterior tract position & &
\end{tabular}

FIS: Wexner fecal incontinence score.
TABLE 5. Anorectal manometry outcomes before versus after surgical treatment for anal fistula in patients underwent sphincter divided.

\begin{tabular}{lccc}
\hline Anorectal manometry & Sex & Mean $(\mathrm{SD})$ & $\boldsymbol{P}$ \\
\hline \multirow{2}{*}{ Resting pressure $(\mathrm{mmHg})$} & Male & $77 \pm 12$ vs $54 \pm 13$ & 0.00 \\
& Female & $77 \pm 23$ vs $56 \pm 08$ & 0.02 \\
& Male & $190 \pm 49$ vs $135 \pm 34$ & 0.00 \\
Squeeze pressure $(\mathrm{mmHg})$ & Female & $160 \pm 47$ vs $100 \pm 27$ & 0.01 \\
\hline
\end{tabular}

Total of patients $=73$ [Male $39(53 \%)$ Female $34(47 \%)]$

having undergone seton placement and fistulotomy. In all cases that underwent LIFT, there were no postoperative changes in the anal pressures or reports of FI.

\section{DISCUSSION}

This study demonstrates that the use of 3D-AUS to assess anal fistula can provide preoperative mapping of the anal fistula, identify all the components, such as, the position and type of the primary and secondary tract(s), internal opening(s), as well as quantify the length of the sphincter muscle to be transected. This makes it possible to plan the best approach for each patient according to the gender, position of the tract and the percentage of sphincter muscle transected by the tract. For decisions regarding postoperative follow-up, 3D-AUS identified the cases of healing and those that had recurrence and needed a further surgical procedure. Furthermore, the 3D-AUS visualized cases with delayed healing without recurrence, for the application of conservative treatment. More importantly, the exam image avoided repeated surgical interventions in two cases, in which only persistent small cavities without tract were identified, and classified five cases of recurrence after the LIFT procedure and two cases after seton placement and fistulotomy. Patients that undergo divided muscles should be followed with images due to the increased risk of fecal incontinence if they have history of vaginal delivery or undergo a further anorectal procedure due to newly developed perianal fistula.

The 3D-AUS with automatic scanning, high frequency and multiplane images makes it possible to provide accurate measures of the length of the muscles and the tract up to the location where it is crossed by the sphincter muscles, with this study comparing the results related to the percentage of the compromised muscles before and after surgery in those patients that underwent a sphincter divided approach. This method is well tolerated and is minimally invasive, because the endoprobe is kept stationary during image acquisition.

Table 4. 3D-us outcomes before and after surgical treatment for anal fistula in patients underwent sphincter divided.

\begin{tabular}{|c|c|c|c|}
\hline Ultrasound finding & $\begin{array}{c}\text { Male } \\
39(53 \%)\end{array}$ & $\begin{array}{c}\text { Female } \\
34(47 \%)\end{array}$ & $P$ \\
\hline Percentage of anterior IAS divided before vs after surgery - mean (SD) & $32 \% \pm 18$ vs $35 \% \pm 17$ & $32 \% \pm 09$ vs $33 \% \pm 10$ & $>0.05$ \\
\hline Percentage of posterior IAS divided before vs after surgery - mean (SD) & $38 \% \pm 13$ vs $39 \% \pm 11$ & $20 \% \pm 08$ vs $26 \% \pm 10$ & $>0.05$ \\
\hline
\end{tabular}

Eas: external anal sphincter; IAS: internal anal sphincter; EAS-PR: external anal sphincter plus puborrectalis muscles. 
In the present study, patients with recurrent cryptogenic fistula, inflammatory bowel disease, human immunodeficiency virus (HIV), anal sphincter injury, fecal incontinence symptoms, a history of vaginal delivery or previous injured muscles according to 3D-AUS were excluded in order to ensure homogeneity in the study population and reduce bias. The 3D-AUS examiners were also blinded before and after the surgery concerning the percentage of muscles transected.

Despite the previous definition of complex anal fistula, including transphincteric fistulas that involve greater than $30 \%$ of the external sphincter ${ }^{(11-13)}$, in the present study, all patients with $\geq 50 \%$ EAS or EAS-PR muscle involvement in males and $\geq 40 \%$ EAS or EAS-PR in females were referred for sphincter preservation surgery, such as LIFT. However, one of the group of three surgeons did not have sufficient training to perform LIFT and chose seton placement and subsequent fistulotomy in two or three steps. The difference in the percentage of muscles compromised according to gender was based on the difference of the anterior length and the distribution of the muscles comparing males with females. The anterior EAS is shorter in females and the percentage of compromised muscles is high ${ }^{(14)}$. Female patients with less than $40 \%$ and males with less than $50 \%$ of striated muscles underwent one-stage fistulotomy. All the techniques presented high healing rates, as reported in the literature ${ }^{(15-19)}$. However, 23/48 (50\%) of the patients that had sphincter muscles divided ( 15 underwent seton and 8 fistulotomy) complained of fecal incontinence, although with low CCFS, similar to the literature that reported incontinence ranging from $4 \%$ to $62 \% 0^{(7,20-22)}$.

The high rate of patients that complained of FI, even with low CCFIS, may be explained by the high values of the percentage of muscle compromised by the tract and referred to sphincter divided surgery stablished in this study in both genders, which failed to select patients that would have good functional results. The results suggest that the percentage of muscles transected should be lower than used in this study, even in those cases where the tract position was in the posterior, as seen in $9 / 48(20 \%)$ cases that complained of FI (five cases underwent seton and four cases fistulotomy). Furthermore, all patients of this study had no associated risk factors, such as, preoperative incontinence, recurrent disease, female gender, complex fistulas, and previous fistula surgery, which could justify the FI symptoms.

Thus, surgeries that preserve the sphincter should be the first option of anal fistula treatment, even considering that these procedures have demonstrated higher rates of recurrence compared to fistulotomy ${ }^{(17-19,23,24)}$. Studies in the literature are controversy concerning the amount of sphincter muscle that can be safely divided in anal fistula, some have reported that the division of less than $30 \%$ of the external anal sphincter carries a minimal risk of postoperative $\mathrm{FI}^{(11-13)}$. Conversely, Garcés-Albir et al. ${ }^{(25)}$. reported that the division of the lower $66 \%$ of the external anal sphincter was associated with excellent rates of continence and healing in patients who lacked risk factors before surgery.

In this study, $1 / 3$ of the patients underwent sphincter-sparing (LIFT) procedures that results in healing in over $80 \%$ of the patients, with the sphincter function preserved in all of them, with similar results presented in the literature ${ }^{(17-19)}$.

As demonstrated in this study, the high accuracy of 3D-AUS in quantifying the percentage of sphincter muscle compromised by the tract before the surgery was demonstrated by the similar results after the surgery, considering the measurements of the percentage of fibrosis that substituted the muscles cut and the percentage of residual muscles. A further study should establish the percentage of muscles that can be divided in different situations, such as, for each tract position (anterior or posterior) and for each gender, to avoid FI symptoms. Weaknesses in the study included the small number of patients in each subgroup, considering the gender, position of the tract and percentage of compromised muscles, which did not allow the parameters to be evaluated separately. In addition, further studies should compare all measurements performed by 3D-AUS imaging with MRI.

\section{CONCLUSION}

The 3D-AUS was shown to be an effective method in the preoperative assessment of anal fistulas by quantifying the length of muscle to be divided, as the results were similar at the post-operative moment, providing a safe treatment approach according to the gender and percentage of muscle involvement. Additionally, 3D-US successfully identified the healing tissue and the type of failure or recurrence.

\section{Authors' contribution}

Murad-Regadas SM: study design, ultrasonography, critical revision for intellectual content. Regadas Filho FSP and Veras LB: data acquisition, interpretation of data and drafting the article. Holanda EC and Lopes MS: data acquisition and drafting the article.

Murad-Regadas SM, Regadas Filho FSP, Holanda EC, Veras LB, Vilarinho AS, Lopes MS. O ultrassom anorretal tridimensional pode ser incluído como um método diagnóstico na avaliação da fístula anal antes e após o tratamento cirúrgico? Arq Gastroenterol.

RESUMO - Contexto - Não há dados definitivos quanto a níveis diferentes na secção do complexo esfincteriano e o efeito na função do canal anal no tratamento das fístulas anais. Objetivo - Avaliar a aplicação do ultrassom anorretal tridimensional no diagnóstico da fístula anal, quantificando o comprimento da musculatura que será seccionada, selecionando pacientes para diferente abordagens e identificando cicatrização e recorrência após tratamento. Métodos - Um estudo prospectivo incluindo paciente portadores de fístula anal criptoglandular, tipo trans-esfinctérica avaliados pelo escore de incontinência fecal, ultrassom anorretal 3D e manometria anorretal antes e após a cirurgia. De acordo com os dados do ultrassom, pacientes do sexo masculino com envolvimento $\geq 50 \%$ do esfíncter externo anterior ou esfíncter externo + puborretal e do sexo feminino com envolvimento $\geq 40 \%$ foram referidos para cirurgia de ligadura do trajeto no espaço inter-esfinctérico (LIFT) ou colocação do sedenho. Aqueles com envolvimento $<50 \%$ em homens e $<40 \%$ mulheres foram indicados para fistulotomia em um tempo. Após a cirurgia, a musculatura secccionada (fibrose) e o músculo residual foram medidos e comparados no pós-operatório. Resultados - Um total de 73 pacientes foi incluído. A indicação para LIFT foi significativamente maior em mulheres $(47 \%)$ e a fistulotomia em homens $(46 \%)$ e o sedenho similar em ambos os sexos. Sintomas de incontinência leve foi identificado em $31 \%$ dos submetidos à cirurgia com divisão de esfíncter e similar em ambos os sexos. O ultrassom identificou sete casos que não cicatrizaram. Conclusão - O ultrassom anorretal tridimensional demonstrou ser um método efetivo na avaliação da fístula anal, quantificando o comprimento do esfíncter a ser dividido, como demonstrado no resultado pós-operatório, fornecendo um tratamento seguro de acordo com sexo e percentual de músculo envolvido. Adicionalmente, identifica o tecido cicatrizado, tipo de recorrência e a falha no tratamento

DESCRITORES - Malformações anorretais. Fístula retal. Incontinência fecal. Ultrassom. 


\section{REFERENCES}

1. Vogel JD, Johnson EK, Morris AM, Paquette IM, Saclarides TJ, Feingold DL, Steele SR. Clinical Practice Guideline for the Management of Anorectal Abscess, Fistula-in-Ano, and Rectovaginal Fistula. Dis Colon Rectum 2016;59:1117-33

2. Gustafsson UM, Kahvecioglu B, Aström G, Ahiström H, Graf W. Endoanal ultrasound or magnetic resonance imaging for preoperative assessment of anal fistula: a comparative study. Colorectal Dis. 2001:3:189-97.

3. West RL, Dwarkasing S, Felt-Bersma RJ, Schouten WR, Hop WC, Hussain SM, Kuipers EJ. Hydrogen peroxide-enhanced three dimensional endoana ultrasonography and endoanal magnetic resonance imaging in evaluating perianal fistulas: agreement and patient preference. Eur J Gastroenterol Hepatol. 2004;16:1319-24

4. Buchanan GN, Halligan S, Bartram CI, Williams AB, Tarroni D, Cohen CR Clinical examination, endosonography, and MR imaging in preoperative as sessment of fistula in ano: comparison with outcome-based reference standard Radiology. 2004;233:674-81

5. Murad-Regadas SM, Regadas FSP, Rodrigues LV, Holanda EC, Barreto RG, Oliveira L. The role of 3-Dimensional anorectal ultrasonography in the assessment of anterior transsphincteric fistula. Dis Colon Rectum. 2010;53:1035-40

6. Garcia-Aguilar J, Belmonte C, Wong WD, Goldberg SM, Madoff RD. Ana fistula surgery: factors associated with recurrence and incontinence. Dis Colon Rectum. 1996;39:723-9.

7. van Tets WF, Kuijpers HC. Continence disorders after anal fistulotomy. Dis Colon Rectum. 1994;37:1194-7.

8. Van Koperen PJ, Wind J, Bemelman WA, Bakx R, Reitsma JB, Slors JFM. Longterm functional outcome and risk factors for recurrence after surgical treatment for low and high perianal fistulas of criptoglandular origin. Dis Colon Rectum. 2008;51:1475-81.

9. Roing JV, Jordán J, García-Armengol J, Esclapez P, Solana A. Changes in anorectal morphologic and functional parameters after fistula-in-ano surgery. Dis Colon Rectum. 2009;52:1462-8.

10. Jorge, JMN, Wexner, SD. Etiology and management of fecal incontinence. Dis Colon Rectum. 199:36:77-97.

11. Kondylis PD, Shalabi A, Kondylis LA, Reilly JC. Male cryptoglandular fistula surgery outcomes: a retrospective analysis. AmJ Surg. 2009;197:325-30.
12. Sangwan YP, Rosen L, Riether RD, Stasik JJ, Sheets JA, Khubchandani IT. Is simple fistula-in-ano simple? Dis Colon Rectum. 1994;37:885-9.

13. Zmora O, Neufeld D, Ziv Y, Tulchinsky H, Scott D, Khaikin M, et al. Prospective, multicenter evaluation of highly concentrated fibrin glue in the treatmen of complex cryptogenic perianal fistulas. Dis Colon Rectum. 2005;48:2167-72.

14. Regadas FSP, Murad-Regadas SM, Lima DMR, Silva FR, Barreto RGL, Souza MHLP, Regadas Filho FSP. Anal canal anatomy showed by three-dimensional anorectal ultrasonography. Surg Endoscopy. 2007;21:2207-11.

15. Davies M, Harris D, Lohana P, Chandra Sekaran TV, Morgan AR, Beynon J, Carr ND. The surgical management of fistula-in-ano in a specialist colorectal unit. Int J Colorectal Dis. 2008;23:833-8.

16. Ritchie RD, Sackier JM, Hodde JP. Incontinence rates after cutting seton treatment for anal fistula. Colorectal Dis. 2009;11:564-71.

17. Sunoda A, Sada H, Sugimoto T, Nagata H, Kano N. Anal function after ligation of the intersphincteric fistula tract. Dis Colon Rectum. 2013;56:898-902.

18. Hong KD, Kang S, Kalaskar S, Wexner SD. Ligation of intersphincteric fistula tract (LIFT) to treat anal fistula: systematic review and meta-analysis. Tech Coloproctol. 2014;18:685-91.

19. Alasari S, Kim NK. Overview of anal fistula and systematic review of ligation of the intersphincteric fistula tract (LIFT). Tech Coloproctol. 2014;18:13-22.

20. Lunniss PJ, Kamm MA, Phillips RK. Factors affecting continence after surgery for anal fistula. Br J Surg. 1994;81:1382-5

21. Cavanaugh M, Hyman N, Osler T. Fecal incontinence severity index after fistulotomy: a predictor of quality of life. Dis Colon Rectum. 2002;45:349-53

22. Ritchie RD, Sackier JM, Hodde JP. Incontinence rates after cutting seton treatment for anal fistula. Colorectal Dis. 2009;11:564-71.

23. Jarrar A, Church J. Advancement flap repair: a good option for complex anorecta fistulas. Dis Colon Rectum. 2011;54:1537-41.

24. Champagne BJ, O'Connor LM, Ferguson M, Orangio GR, Schertzer ME, Armstrong DN. Efficacy of anal fistula plug in closure of cryptoglandular fistulas: long-term follow-up. DisColon Rectum. 2006;49:1817-21.

25. Garcés-Albir M, García-Botello SA, Esclapez-Valero P, Sanahuja-Santafé A Raga-Vázquez J, Espi-Macías A, Ortega-Serrano J. Quantifying the extent of fistulotomy. How much sphincter can we safely divide? A three-dimensional endosonographic study. Int J Colorectal Dis. 2012;27:1109-16. 